\title{
Evaluate the Profitability in Commercial Bank Comparative Study of Indian and Jordanian Banks
}

\author{
Dr Ali Mahmoud Abdallah Alrabei \\ Department of Accounting, Faculty of Economic and Business \\ Jadara University \\ E-mail: alialrabei@yahoo.com
}

Received: Feb. 19, $2013 \quad$ Accepted: April 19, $2013 \quad$ Published: June 1, 2013

doi:10.5296/ajfa.v5i1.3280 URL: http://dx.doi.org/10.5296/ajfa.v5i1.3280

\begin{abstract}
Banks and financial institutions are the backbone of the economy of the country everywhere, in India, Jordan and all over the world. Profitability is one of the major criteria for evaluating the performance of a bank; the present study is confined to the State Bank of India (SBI) and Cairo Amman Bank (CAB), Jordan. The period of study is from 2006-07 to 2010-11. It has to be noted that the accounting year of SBI is from April to March while in the case of CAB the accounting year starts from 1st Jan and ends on 31st Dec. There are two sources of date i.e. primary data and secondary data. The primary data is original in nature. The primary data has been collected through personal interviews with the officials of the banks. The secondary data have been collected through published annual reports, magazine and internet. Mainly the present study is based on the secondary data. The study finding the State Bank of India should try to control the cost of services rendered to increase the gross profit, and the Cairo Amman Bank should try to increase the number of branches at global level also.
\end{abstract}

Keywords: Evaluate, Profitability, Commercial Banks, Jordan, India 


\section{Introduction}

Profit is the prima facie object of every business. A business can not breathe well without profits. It may be considered as a mirror of the operating performance of a company. In the words of Lord Keynes, "Profit is the engine that drives the business enterprise." A business needs profit not only for its existence but also for the expansion and diversification. "Profit is the barometer of the success of the business. It is indeed, a magic eye that mirrors all aspects of entire business operations including the quality of output." ${ }^{(2)}$ Profits are the soul of the business without which it is lifeless. In fact, profits are useful intermediate beacon towards which a firm's capital should be directed. ${ }^{(4)}$ M.E. Murphy has rightly remarked that "Business cannot exist without profits, as an economy cannot exist without sound business. Profits must be something for all to be proud of; they should not be suspected." ${ }^{\prime(6)}$

In accounting, profit is defined as "excess of revenues over related cost applicable to transaction a group of transactions or to the transactions of an operating period." ${ }^{,(5)}$

In the words of R.L.Smith "The term 'profit' carries a variety of meanings not only in technical sense but in interpretative sense as well." (10)

The company's financial information is contained in Balance Sheet and Profit and Loss Account. The figures contained in these statements are absolute and sometimes unconnected with one another. An absolute figure does not convey much meaning. However, it is only in the light of other information that the significance of a figure is realized. For example, $\mathrm{Mr} \mathrm{X}$ weighs $50 \mathrm{Kgs}$. Is he fat? We can not give answer unless we know his age and height. Similarly a company's profitability cannot be known unless together with the amount of profit, the capital employed is also seen. The relationship of these two figures expressed mathematically is a Ratio. The ratio refers to the numerical or quantitative relationship with the other. The ratio refers to the numerical or quantitative relationship between two variables or items. A ratio is calculated by dividing one item of the relationship with the other. The ratio analysis is one of the most useful and common method of analyzing financial statements. As compared to other tools of financial analysis, the radio analysis provides very useful conclusions about various aspects of the working of the business. The need for ratio arises due to the fact that absolute figures and often misleading. Absolute figures are certainly valuable but their value increases manifold if they are studied with another through ratio analysis. Ratios enable the mass of data to be summarized and simplified. Ratio analysis is an instrument for diagnosis of the financial health of an enterprise. Ratios, in fact, are full of meaning and communicate the relative importance of the various items appearing in the Balance sheet and Profit and Loss Account.

\section{Literature Review}

Xuezhi Qin \& Dickson Pastory. ${ }^{(12)}$ Commercial Banks Profitability Position: The Case of Tanzania. The study examines commercial banks profitability in Tanzania for the period of ten years (2000-2009). The study used National Microfinance Bank (NMB), National Bank of Commerce (NBC) and CRDB as the case study. The study employed the profitability measures of commercial banks, and the evidence of performance in terms of profitability was 
established based on return on average asset, net interest income to average bearing assets and non-interest expenses to average assets. The paper utilized panel secondary data from National bank of commerce, CRDB and National Microfinance bank in Tanzania for the period of ten years, and the hypothesis was tested to know whether there is a significant difference in terms of profitability by using ANOVA test. Finally the regression model was run to see the effects of capital adequacy, liquidity and asset quality on the profitability of commercial banks. The findings revealed that there is no significant difference on profitability among the commercial banks, in the context of regression model it has been noted that liquidity and asset quality has positive impact in profitability with exception to the level of nonperforming loans which has a negative influence on profitability. Also capital adequacy has shown negative impact on profitability. The study confirmed the profitability of commercial banks to stable and meeting the regulatory requirement of the Bank of Tanzania (BOT).

John Goddard, Phil Molyneux and John O. S. Wilson. (2004) ${ }^{(3)}$. The profitability of European banks during the $1990 \mathrm{~s}$ is investigated using cross-sectional, pooled cross-sectional time-series and dynamic panel models. Models for the determinants of profitability incorporate size, diversification, risk and ownership type, as well as dynamic effects. Despite intensifying competition there is significant persistence of abnormal profit from year to year. The evidence for any consistent or systematic size-profitability relationship is relatively weak. The relationship between the importance of off-balance-sheet business in a bank's portfolio and profitability is positive for the UK, but either neutral or negative elsewhere. The relationship between the capital-assets ratio and profitability is positive.

Mohammad Khurram Manzoor, Hassan H. Sumra and Momina Abbas. (2011) ${ }^{(8)}$. under the title,'The Impact of E-Banking on the Profitability of Banks: A Study of Pakistani Banks" This research paper aims at examining the impact of electronic banking on the profits of Pakistani banks. E banking has increased the competition among the banks and both domestic and foreign banks are offering more and more modern ways of e-banking. The study investigates the services provided by the banks and their impact on their profitability in particular. It is significant due to the proliferation of the service sector and its importance in the economy. It also discusses about the services provided by the banks to its customers and also reveals the major rationales for the banks to use internet and other electronic mediums as the means to providing services to their customers. It is a distinguished one because it reveals the factors which lead to the success of the operations, giving more profits and the ability to manage risks of using electronic means and using the electronic services for the benefit of the bank and how they differentiate through these services in the market and the factors which lead to the increased profitability of banks, be it public or private.

Mohammad Abu Sayeed, Piyadasa Edirisuriya and Mohammad Hoque. (2012) ${ }^{(7)}$. Bank Profitability: The Case of Bangladesh, This study attempts to examine the impact of asset and liability management on the profitability of commercial banks in Bangladesh. Commercial banks are segmented into high profitable and low profitable and private and public banks. While applying Statistical Cost Accounting (SCA) methods study finds high earning banks experience higher returns from their assets and lower returns from their liabilities than the 
low earning banks. Results are inconclusive with regard to private banks' and public banks' returns. This study finds that assets management of large commercial banks is better than those of small banks, but they are not better than small banks in respect of liability management.

Vasiliou, D. (1996) $)^{(11)}$. Linking profits to Greek production management, investigated portfolio of assets and liabilities between high-profit and low-profit Greek banks by employing SCA method. His regression results suggest that it is the asset management rather than liability management that play more prominent role in explaining interbank differences in profitability. This study implies that high profit banks earn higher return on their assets than that of low profit banks. At the same time high profit banks enjoy lower expenses for their liabilities. These findings contrast with the findings of Kosmidou et al (2004) who find that liability management contributes more in creating the profitability differences among the banks.

Rasidah Mohd Said, and Mohd Hanafi Tumin. $(2011)^{(9)}$. Performance and Financial Ratios of Commercial Banks in Malaysia and China. This study aims to investigate the impact of bank-specific factors which include the liquidity, credit, capital, operating expenses and the size of commercial banks on their performance, which is measured by return on average assets (ROAA) and return on average equity (ROAE). The results imply that ratios employed in this study have different effects on the performance of banks in both countries, except credit and capital ratios. Operating ratios influence performance of banks in China, but this influence is not true for Malaysian banks regardless of the measure of performance.

Ali Alp, Ünsal Ban, Kartal DEMİRGÜNEŞ, and Saim Kilic. (1997) $)^{(1)}$. Internal Determinants of Profitability in Turkish Banking Sector. The aim of this study is to identify the internal determinants of profitability of Turkish banks in the period of 2002-2009. The importance of the study derives from the fact that finding out the mentioned determinants is a necessity for both the managers of Turkish banks who successfully operates -even in times of financial crisis-, and existing (and potential) national and international investors. Findings of the study indicate that capital efficiency and size affect profitability positively, while liquidity and operating costs negatively.

\section{Problem of the Study}

An analysis of the profitability reveals how the profit position stands as a result of total transactions made during a year. Such analysis is particularly interesting to suppliers of funds who can evaluate their investment and take decision accordingly. On the other hand, profit ratios are equally beneficial to the management because these ratios reflect the efficiency of the enterprise as whole. And the question that mentions here is how Evaluate the Profitability Effect in Commercial Banks.

\section{Significance of the Study}

The word profitability may be defined as the ability of a given investment to earn a return from its use. The state of profitability is a variable thing like temperature and humidity of a day. The definition of profitability by an accountant and or analyst can even be linked to 


\section{Macrothink}

Asian Journal of Finance \& Accounting

ISSN 1946-052X

2013, Vol. 5, No. 1

temperature reading and study of humidity by meteorologist. The present wealth of a day is recorded so that prospects can be forecasted. Profitability has been considered, to a great extent, as one of the main criteria to judge the extent to which management has been successful in maximizing its profits or minimizing it loses, if any.

The concept of profit is related to absolute figures. It does not tell about the reason how it takes place or the relationship of this figure with another one. These questions can be answered by a peep into the profitability of an entity. Profit, as an absolute term, has no relevance to compare the efficiency of organizations. A very high profit does not always indicate a sound organizational efficiency and a low profitability not always a sign of organizational sickness. In many a situation it so happens that when a concern is implementing expansion plans, it may run into short term losses. Therefore, it can be said that profit is not the prime variable on which the operational efficiency and financial efficiency of an organization can be compared.

\section{Objectives of the study}

The present research work seeks to examine the effect of profitability on performances of Commercial Banks. The following are the important objectives of the study:

1) To find evaluate the profitability on the gross profit ratio between SBI and CAB.

2) To find evaluate the profitability on the Net Profit Ratio between SBI and CAB

3) To find evaluate the profitability on the Operating Profit Ratio between SBI and CAB.

4) To find evaluate the profitability on the Operating Ratio between SBI and CAB.

5) To find evaluate the profitability on the Return on Equity Share Holder's Fund between SBI and CAB.

6) To find evaluate the profitability on the Return on Capital Employed Ratio between SBI and $\mathrm{CAB}$.

7) To find evaluate the profitability on the Return on Total Assets Ratio between SBI and CAB.

\section{Research Methodology}

The study is based on the following methodology.

\subsection{Nature of Data}

The data required for the purpose of the study are the following in nature:

1. Information relating to the formation, growth, operational jurisdiction, financial activities and programmes of Commercial Banks.

2. Balance sheet, Profit and Loss account published in the form of annual reports of Commercial Banks. 


\section{Macrothink}

Asian Journal of Finance \& Accounting

ISSN 1946-052X

2013, Vol. 5, No. 1

3. Statistical summary of all scheduled commercial banks in Jordan published in annual reports of Commercial Banks present and past practices.

4. Banking statistics published in the Central Bank of Jordan bulletin.

\subsection{Sources of Data}

Most of the information collected for the study will be secondary in nature. The secondary data will be collected from the following sources:

Information relating to scheduled commercial bank offices will be obtained from the Bank.

Annual reports of banks.

\subsection{Period of Study}

The period of study spans over the years between year 2006/2007 to 2010/2011. . It has to be noted that the accounting year of State Bank of India (SBI) is from April to March while in the case of Cairo Amman Bank (CAB) the accounting year starts from $1^{\text {st }}$ Jan and ends on $31^{\text {st }}$ Dec. The period of five years has been taken mainly to analyze the impact of profitability of Commercial Banks. Incidentally this is most significant period, in the life of Banks because the profits are more or less volatile during the period. Thus, the study covers a period of five years from 2006/2007 to 2010/2011.

6.4 Scope of the study: - In the present study following banks have been covered

State Bank of India (SBI)

Cairo Amman Bank, Jordan (CAB)

6.5 Hypotheses of the study

H1 There is no significant difference in gross profit ratio between SBI and CAB

H2 There is no significant difference in Net Profit Ratio between SBI and CAB

H3 There is no significant difference in Operating Profit Ratio between SBI and CAB

$\mathrm{H} 4$ There is no significant difference in Operating Ratio between SBI and CAB

H5 There is no significant difference in Return on Equity Share Holder's Fund between SBI and $\mathrm{CAB}$

H6 There is no significant difference in Return on Capital Employed Ratio between SBI and $\mathrm{CAB}$

H7 There is no significant difference in Return on Total Assets Ratio between SBI and CAB.

\subsubsection{First Hypothesis}

$\mathrm{H1}$ : There is no significant difference in gross profit ratio between $\mathrm{SBI}$ and $\mathrm{CAB}$

The gross profit ratio of SBI (India) and CAB (Jordan) has been presented in the table 1.1 
It can be visualized from the table 1.1 that the gross profit ratio in SBI, India showed a fluctuating trend and varied within the range of 40.39 percent in 2006-07 to 23.26 percent in 2009-10 i.e. the range of total variation was 17.13 percent. On the other hand the gross profit ratio in $\mathrm{CAB}$, Jordan almost showed a consistent trend during the period of study except in the year 2008-09 and varied within the range of 71.72 percent in 2010-11 to 16.37 percent in 2008-09. The width of range was very high i.e., 55.35 percent which is not favourable for the bank. .The average of gross profit ratio in SBI, India was 32.24 percent while for CAB, Jordan it was 59.76 percent. From average point of view $\mathrm{CAB}$, Jordan is better placed and signifies that the cost of services rendered is less in comparison to the cost of services rendered by SBI, India. It denotes an effective management. The variations were high in $\mathrm{CAB}$, Jordan because the coefficient of variation in CAB, Jordan was 36.32 percent while in SBI, India it was 16.89 percent. It is suggested that the management of SBI, India should try to reduce and control the cost of services rendered while the management of $\mathrm{CAB}$, Jordan should try to maintain the same pattern of gross profit ratio but try to control the fluctuations.

Test of Significance (t test for two sample means):- to apply the $t$ test, let the hypothesis be that the gross profit ratio of both the banks is same and there is no significant difference

Computed Value of $\mathrm{t}$ for two sample means $=2.75$

Table value of $t$ at 5 percent level of significance (for $v=5+5-2=8$ ) is 2.306

Since the calculated value of $\mathrm{t}$ (2.75) is more than the table value (2.306), hence there is no evidence of accepting the hypothesis. Therefore, the hypothesis is rejected and it is concluded that the gross profit ratio of both the banks differs significantly or it can be inferred that the gross profit ratio of $\mathrm{CAB}$, Jordan is better than the gross profit ratio of SBI, India.

\subsubsection{Second Hypothesis}

H2: There is no significant difference in Net Profit Ratio between SBI and CAB

Inter Bank Comparison: - A comparative study of both the banks with regard to net profit ratio can be made through the table 1.2

It can be observed from the table 1.2 that the net profit ratio in SBI, India showed a consistent trend up to the year 2008-09 and then after a decreasing trend. The net profit ratio varied within the range of 12.89 percent in 2007-08 to 9.84 percent in 2010-11, hence the variations were not high but however, the profitability was low. On the other hand the net profit ratio in $\mathrm{CAB}$, Jordan showed a decreasing cum increasing trend and varied within the range of 27.73 percent in 2010-11 to 19.66 percent in 2008-09 denoting that the range of variations in the net profit ratio was higher in $\mathrm{CAB}$, Jordan than $\mathrm{SBI}$, India. It can further be noted that the net profit ratio in SBI was in proportion to gross profit ratio whereas the gross profit ratio in CAB was very high and in comparison to gross profit ratio the net profit ratio of $\mathrm{CAB}$ can not be regarded satisfactory as it implies that the bank had to spend a lot on the indirect cost of operations which should be controlled. Net profit ratio of both the banks showed a consistent trend as the coefficient of variation in SBI, India was 8.76 percent and for CAB, Jordan it was 11.50. However, it is suggested that the management of CAB, Jordan should try to control the 
fluctuations. On the whole it can be said that the net profit ratio of CAB, Jordan was greater than the net profit ratio of SBI, India.

\section{Test of Significance of Net Profit Ratio (t test for 2 sample means)}

To apply the $t$ test for net profit ratio of both the banks following hypotheses have been used

(i) Null Hypothesis(Ho):- There is no significant difference in the net profit ratio of both the banks

(ii) Alternative Hypothesis (Ha):- The net profit ratio in $\mathrm{CAB}$, Jordan is better than the net profit ratio of SBI, India.

Calculated Value of $t$ for two sample means $=9.10$

Degree of freedom $(v)=5+5-2=8$

Table value of $t$ at 5 percent level of significance (for $v=8$ ) $=2.306$

Decision: As the calculated value of $t$ is more than the table value, hence the null hypothesis is rejected and alternative hypothesis is accepted and it is concluded that the net profit ratio in $\mathrm{CAB}$, Jordan is better than the net profit ratio of SBI, India.

\subsubsection{Third Hypothesis}

H3: There is no significant difference in Operating Profit Ratio between SBI and CAB Inter Bank Comparison

The table 1.3 shows inter firm comparison of the banks for operating profit ratio. It can be noted from the table (1.3) that there was no operating profit in SBI, India accordingly the operating profit ratio was negative throughout the period under study and it fluctuated within the range of -3.33 percent in 2008-09 to -16.19 percent in 2009-10 while the operating profit ratio in Cairo Amman Bank showed an increasing trend except in the year 2009-10. The average of the operating profit ratio in SBI was -8.25 percent, which denotes inefficiency of management and it is suggested that the management should try to control operating expense to increase this ratio. The average of the operating profit ratio in Cairo Amman Bank was 51.93 percent denoting an efficient management and proper control over the operating cost of the business. Through the inter bank comparison it can be stated that the performance of $\mathrm{CAB}$, Jordan was better than SBI, India.

\section{Test of Significance for Operating Profit Ratio (t test for two sample means)}

Hypotheses:

(i) Null Hypothesis(Ho):- There is no significant difference in the operating profit ratio of both the banks

(ii) Alternative Hypothesis (Ha):- The operating profit ratio in $\mathrm{CAB}$, Jordan is better than the operating profit ratio of SBI, India.

Calculated value of $t$ for the mean values of Operating profit $=21.43$ 
Degree of freedom $(\mathrm{v})=5+5-2=8$

Table value of $t$ at 5 percent level of significance for $v=8$ is 2.306

Decision:- Since the calculated value of $t$ is more than the table value, therefore, the null hypothesis is rejected and alternative hypothesis is accepted and concluded that the difference in the operating profit ratio of SBI and $\mathrm{CAB}$ is significant. On account of accepting alternative hypothesis it is inferred that the operating profit ratio of CAB, Jordan is better than SBI, India.

\subsubsection{Fourth Hypothesis}

H4: There is no significant difference in Operating Ratio between SBI and CAB

Inter Bank Comparison

The operating ratio of both the banks under study has been shown collectively in the table 1.4

It is evident from the table 1.4 that the operating ratio in SBI is greater than the operating income resulting into operating loss. It denotes that the operating cost in SBI is excessively high not being covered by the operating incomes. The average of the operating ratio in SBI is 108.25 percent. The management of SBI should either reduce the operating cost or increase the operating incomes to convert the operating loss into operating profit. It can be noted from the table that the management failed to control the operating cost as the operating ratio increased during 2009-10 and 2010-11. It shows inefficiency of management. On the other hand, the operating ratio in $\mathrm{CAB}$, Jordan almost showed a decreasing trend which denotes an effective management and control over unnecessary operating cost. The coefficient of variation was 6.00 percent denoting a consistent trend. The management of CAB should try to maintain the same position in future also.

\subsubsection{Fifth Hypothesis}

H5: There is no significant difference in Return on Equity Share Holder's Fund between SBI and $\mathrm{CAB}$.

\section{Inter Bank Comparison}

A comparative study of return on equity shareholder's funds as shown in the table 1.5 it can be noted that the return on shareholder's funds showed a decreasing trend in SBI, India except in the year 2008-09 whereas this ratio showed an increasing trend in CAB, Jordan. The average of the ratio was 14.78 percent for SBI, India and 14.61 percent for $\mathrm{CAB}$, Jordan. From average point of view the performance of both the banks is same. However, the rate of return on equity shareholder's funds can be increased if the operating cost is decreased and operating incomes are increased by the management of the bank. The fluctuations in the ratio of SBI were less as the coefficient of variation was 5.36 percent while the variations in $\mathrm{CAB}$ were high because the coefficient of variation was 8.18 percent which should be controlled by the management.

\section{Test of Significance for Return on Equity Shareholder's funds (t test)}

Null Hypothesis (Ho)-there is no significant difference in the return on equity shareholders' funds of the banks under study 
Alternative Hypothesis (Ha)-There is significant difference in the return on equity shareholders' funds and $\mathrm{CAB}$, Jordan has performed better than SBI, India

Computed value of $\mathrm{t}$ for the difference of the mean values $=0.263$

Table value of $\mathrm{t}(\mathrm{v}=8)$ at $5 \%$ level of significance $=2.306$

As the computed value of $\mathrm{t}$ is less than the table value, hence the null hypothesis is accepted and it is inferred that both the banks have performed equally good as regards the return on equity shareholder's funds.

\subsubsection{Sixth Hypothesis}

H6: There is no significant difference in Return on Capital Employed Ratio between SBI and $\mathrm{CAB}$

\section{Inter Bank Comparison}

A comparative study of the return on capital employed of both the banks has been highlighted in the table 1.6. It can be observed from the table (1.6) that the return on capital employed in SBI, India was very than the return on capital employed of CAB, Jordan. The average of the ratio in SBI was just 1.48 percent while in $\mathrm{CAB}$ it was 33.90 percent indicating that the management of $\mathrm{CAB}$ was very efficient to make an optimum use of the resources. The management of SBI should plan their investment policy to yield an optimum return. The consistency in the return on capital employed was higher in CAB than the consistency in SBI, India.

\section{Test of Significance (t test) for Return on Capital Employed}

Hypothesis -

a) Null Hypothesis (Ho)- There is no significant difference in the return on capital employed ratio of the banks under study

b) Alternative Hypothesis (Ha)-The performance of CAB is better than SBI as regards the return on capital employed

Computed value of $t$ for the mean values $=26.68$

Table value of t at 5 percent level of significance for d.f. 8 is 2.306

Decision: - The calculated value of $t$ is higher than the table value, hence the null hypothesis is rejected and alternative hypothesis is accepted. Accordingly it is concluded that the return on capital employed in CAB, Jordan is higher than the return on capital employed in SBI, India.

\subsubsection{Seventh Hypothesis}

H7: There is no significant difference in Return on Total Assets Ratio between SBI and CAB Inter Bank Comparison

The table 1.7 shows a comparative position of both the banks for return on total assets. It can be 
observed from the table (1.7) that the return on total assets in SBI, India was less than the return on total assets in $\mathrm{CAB}$, Jordan. The average rate of return on total assets in SBI was 1.32 percent while in $\mathrm{CAB}$, Jordan it was 3.68 percent which means that the total assets were used in $\mathrm{CAB}$, Jordan effectively in comparison to SBI, India. The variations were high in SBI, India as the coefficient of variation in SBI was 10.30 percent while in $\mathrm{CAB}$, Jordan it was 4.55 percent. It can be concluded that the return on total assets was better in $\mathrm{CAB}$, Jordan.

\section{Test of Significance for return on total assets (t test)}

Hypothesis:

a) Null Hypothesis: - There is no significant difference in the return on total assets of both the banks under study.

b) Alternative Hypothesis:- The return on total assets in CAB, Jordan is more than the rate of return on total assets in SBI, India.

Computed value of $\mathrm{t}=23.90$

Table value of $t$ at 5 percent level of significance $=2.306$

Decision: - Since the computed value of $t$ is more than the table value, the null hypothesis is not accepted and it can be concluded that the rate of return on total assets in $\mathrm{CAB}$, Jordan is more than that of SBI, India.

\section{Conclusions}

1) Test of significance has been carried out by applying $t$ test. Since the calculated value of $t$ (2.75) is more than the table value (2.306), hence there is no evidence of accepting the hypothesis. Therefore, the hypothesis is rejected and it is concluded that the gross profit ratio of both the banks differs significantly or it can be inferred that the gross profit ratio of $\mathrm{CAB}$, Jordan is better than the gross profit ratio of SBI, India.

2) As the calculated value of $t$ is more than the table value, hence the null hypothesis is rejected and alternative hypothesis is accepted and it is concluded that the net profit ratio in $\mathrm{CAB}$, Jordan is better than the net profit ratio of SBI, India.

3) Since the calculated value of $t$ is more than the table value, therefore, the null hypothesis is rejected and alternative hypothesis is accepted and concluded that the difference in the operating profit ratio of $\mathrm{SBI}$ and $\mathrm{CAB}$ is significant. On account of accepting alternative hypothesis it is inferred that the operating profit ratio of $\mathrm{CAB}$, Jordan is better than SBI.

4) As the computed value of $t(0.263)$ is less than the table value (2.306) at 5 percent level of significance, hence the null hypothesis is accepted and it is inferred that both the banks have performed equally good as regards the return on equity shareholder's funds.

5) The calculated value of $t$ is higher than the table value, hence the null hypothesis is rejected and alternative hypothesis is accepted. Accordingly it is concluded that the return on capital employed in $\mathrm{CAB}$, Jordan is higher than the return on capital employed in SBI. 


\section{Macrothink}

6) Since the computed value of $t$ test is more than the table value, the null hypothesis is not accepted and it can be concluded that the rate of return on total assets in $\mathrm{CAB}$, Jordan is more than that of SBI, India.

\section{Recommendations}

1. State Bank of India should try to control the cost of services rendered to increase the gross profit.

2. State Bank of India should also try to control and reduce the indirect cost to increase the net profit and maintain consistency in the net profit ratio.

3. State Bank of India should follow a strict credit policy to avoid unnecessary losses and try to control operating cost which was more than 100 percent.

4. Cairo Amman Bank should try to maintain the same position in future also because its operating cost was under control and the gross profit as well as the net profit ratio showed a satisfactory trend.

5. The Cairo Amman Bank should try to increase the number of branches at global level also.

\section{References}

Ali, A.,Ünsal, B., Kartal, \& Demirgüneş, Kilic. (1997). Internal Determinants of Profitability in Tyrkish Banking Sector. The ISE Review, 12, 1301-1642. http://dx.doi.org/10.2139/ssrn.1231064

Argenti, John. (1968). Corporate Planning - A Practical Guide. George Allen and Unwin Ltd., London.

John, G., \& Phil, M., \& John, O. S. (2004).The Profitability of European Banks: A Cross-Sectional and Dynamic Panel Analysis. The Manchester School, London.

Joseph, F., \& Bradley. (1964). Administrative Financial Management.

Kohler, L., \& Eric. (1984). A Dictionary for Accountants, Prentice Hall of India Private Limited, New Delhi.

Murphy, M. E. (2007). Managerial Accounting. Indian Reprint: Affiliated East - West press, New Delhi.

Mohammad, Abu Sayeed., \& Piyadasa, Edirisuriya., \&Mohammad, Hoque. (2012). Bank Profitability: The Case of Bangladesh. International Review of Business Research Papers, 8(4), 157-176.

Mohammad, Khurram., \& Manzoor. H H., \& Momina, Abbas. (2011). The Impact of E-Banking on the Profitability of Banks: A Study of Pakistani Banks. Journal of Public Administration and Governance, 1(1). http://dx.doi.org/10.1080/09669582.2012.709859 


\section{Macrothink}

Asian Journal of Finance \& Accounting ISSN 1946-052X 2013, Vol. 5, No. 1

Rasidah, M., S., \& Mohd, H.T. (2011). Performance and Financial Ratios of Commercial Banks in Malaysia and China. International Review of Business Research Papers, 7(2), 157-169. http://dx.doi.org/10.1016/j.omega.2010.08.001

Smith, R., L. (1992). Management Accounting, Prentice Hall, New Jersey.

Vasiliou, D. (1996). Linking profits to Greek production management. International Journal of Production Economics, 43, 67-73. http://dx.doi.org/10.1080/0960310042000293146

Xuezhi, Qin., \& Dickson, Pastory. (2012). Commercial Banks Profitability Position: The Case of Tanzania, International Journal of Business and Management, 7(13). http://dx.doi.org/10.5539/ijbm.v7n13p136

Table 1. Gross Profit Ratio of the Banks under Study (From 2006-07 to 2010-11) (Ratio in Percentage)

\begin{tabular}{|l|l|l|}
\hline Years & SBI & Cairo Amman Bank \\
\hline $2006-07$ & 40.39 & 71.04 \\
\hline $2007-08$ & 32.21 & 69.67 \\
\hline $2008-09$ & 33.28 & 16.37 \\
\hline $2009-10$ & 23.26 & 69.98 \\
\hline $2010-11$ & 32.05 & 71.72 \\
\hline Average & 32.24 & 59.76 \\
\hline S.D. & 5.44 & 21.70 \\
\hline C.V.(\%) & 16.89 & 36.32 \\
\hline
\end{tabular}

Source: Annual Reports \& Accounts the Banks under study for the period from 2006-07 to 2010-11.

Table 2. Net Profit Ratio of the Banks Under Study (From 2006-07 to 2010-11)

\begin{tabular}{|c|c|c|}
\hline Years & SBI, India & Cairo Amman Bank, Jordan \\
\hline $2006-07$ & 12.18 & 25.52 \\
\hline $2007-08$ & 12.89 & 23.18 \\
\hline $2008-09$ & 12.19 & 19.66 \\
\hline $2009-10$ & 12.00 & 22.64 \\
\hline $2010-11$ & 9.84 & 27.73 \\
\hline Average & 11.82 & 23.74 \\
\hline S.D. & 1.04 & 2.73 \\
\hline C.V.(\%) & 8.76 & 11.50 \\
\hline
\end{tabular}

Source: Annual Reports \& Accounts the Banks under study for the period from 2006-07 to 2010-11. 
Table 3. Operating Profit Ratio of the Banks under Study (From 2006-07 to 2010-11)

\begin{tabular}{|c|c|c|}
\hline Years & SBI & Cairo Amman Bank \\
\hline $2006-07$ & -3.35 & 46.81 \\
\hline $2007-08$ & -4.59 & 50.76 \\
\hline $2008-09$ & -3.33 & 53.78 \\
\hline $2009-10$ & -16.19 & 53.50 \\
\hline $2010-11$ & -13.81 & 54.78 \\
\hline Average & -8.25 & 51.93 \\
\hline S.D. & 5.58 & 2.88 \\
\hline C.V.(\%) & -67.62 & 5.55 \\
\hline
\end{tabular}

Source: Annual Reports \& Accounts the Banks under study for the period from 2006-07 to 2010-11.

Table 4. Operating Ratio of the Banks under Study (From 2006-07 to 2010-11)

\begin{tabular}{|c|c|c|}
\hline Years & SBI & Cairo Amman Bank \\
\hline $2006-07$ & 103.35 & 53.19 \\
\hline $2007-08$ & 104.59 & 49.24 \\
\hline $2008-09$ & 103.33 & 46.22 \\
\hline $2009-10$ & 116.19 & 46.50 \\
\hline $2010-11$ & 113.81 & 45.22 \\
\hline Average & 108.25 & 48.07 \\
\hline S.D. & 5.58 & 2.88 \\
\hline C.V.(\%) & 5.15 & 6.00 \\
\hline
\end{tabular}

Source: Annual Reports \& Accounts the Banks under study for the period from 2006-07 to 2010-11.

Table 5. Return on Equity Share's Holder Fund Ratio of the Banks Under Study (From 2006-07 to 2010-11)

\begin{tabular}{|c|c|c|}
\hline Years & SBI & Cairo Amman Bank \\
\hline $2006-07$ & 15.56 & 13.92 \\
\hline $2007-08$ & 15.04 & 14.42 \\
\hline $2008-09$ & 15.43 & 13.40 \\
\hline $2009-10$ & 14.45 & 14.43 \\
\hline $2010-11$ & 13.39 & 16.87 \\
\hline Average & 14.78 & 14.61 \\
\hline S.D. & 0.79 & 1.20 \\
\hline C.V.(\%) & 5.36 & 8.18 \\
\hline
\end{tabular}

Source: Annual Reports \& Accounts the Banks under study for the period from 2006-07 to 2010-11. 
Table 6. Return on Capital Employed Ratio of the Banks under Study (From 2006-07 to 2010-11)

\begin{tabular}{|c|c|c|}
\hline Years & SBI & Cairo Amman Bank \\
\hline $2006-07$ & 1.50 & 34.82 \\
\hline $2007-08$ & 1.71 & 36.85 \\
\hline $2008-09$ & 1.60 & 35.41 \\
\hline $2009-10$ & 1.33 & 33.12 \\
\hline $2010-11$ & 1.25 & 29.27 \\
\hline Average & 1.48 & 33.90 \\
\hline S.D. & 0.17 & 2.60 \\
\hline C.V.(\%) & 11.44 & 7.67 \\
\hline
\end{tabular}

Source: Annual Reports \& Accounts the Banks under study for the period from 2006-07 to 2010-11.

Table 7. Return on Total Assets Ratio of the Banks under Study (From 2006-07 to 2010-11)

\begin{tabular}{|c|c|c|}
\hline Years & SBI & Cairo Amman Bank \\
\hline $2006-07$ & 1.34 & 3.55 \\
\hline $2007-08$ & 1.50 & 3.97 \\
\hline $2008-09$ & 1.41 & 3.78 \\
\hline $2009-10$ & 1.21 & 3.58 \\
\hline $2010-11$ & 1.12 & 3.54 \\
\hline Average & 1.32 & 3.68 \\
\hline S.D. & 0.14 & 0.17 \\
\hline C.V.(\%) & 10.30 & 4.55 \\
\hline
\end{tabular}

Source: Annual Reports \& Accounts the Banks under study for the period from 2006-07 to 2010-11. 